Andrés Rodríguez-Pose*

Yannis Psycharis**

Vassilis Tselios***

* London School of Economics and GEN

** Panteion University of Social and Political Sciences

*** University of Thessaly

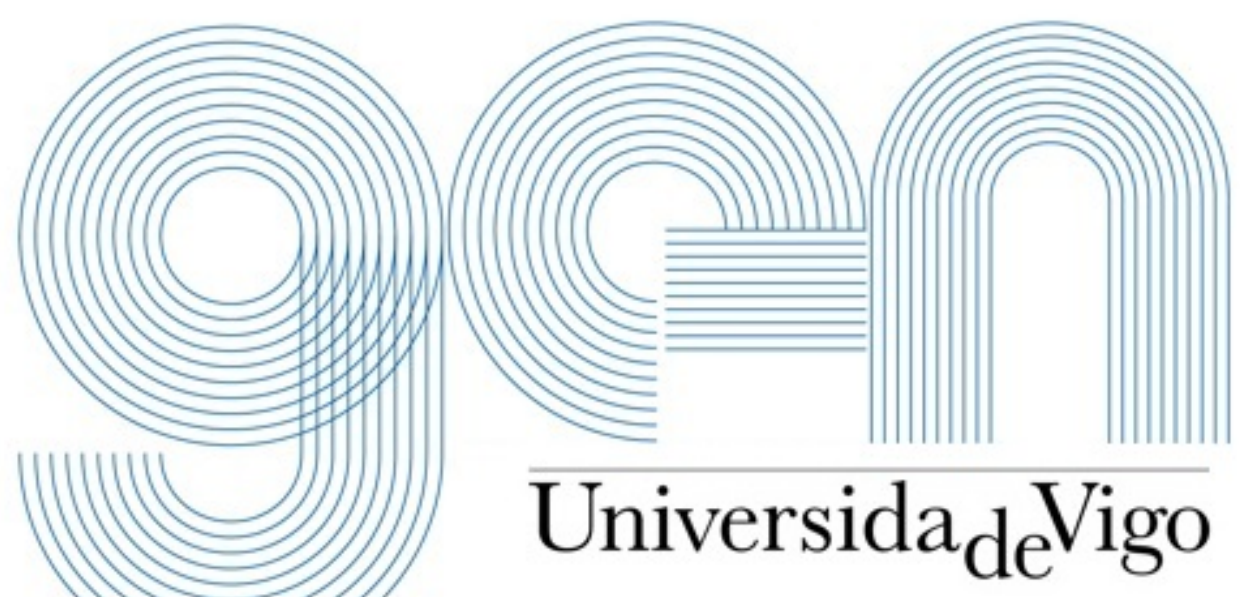




\title{
Politics and investment: examining the territorial allocation of public investment in Greece
}

\author{
by \\ Andrés Rodríguez-Pose*, Yannis Psycharis** and \\ Vassilis Tselios***
}

\author{
Authors' addresses: \\ *Department of Geography and Environment \\ London School of Economics \\ Houghton St \\ London WC2A 2AE, UK \\ Tel: +44 (0)207 9557971 \\ Fax: +44 (0)207955 7412 \\ E-mail: a.rodriguez-pose@lse.ac.uk \\ **Department of Economic and Regional Development \\ Panteion University of Social and Political Sciences \\ 136 Syngrou Avenue \\ 17671 Athens, Greece \\ Tel: +30 2109201722 \\ Fax: +30 2109232979 \\ E-mail: psycharis@panteion.gr \\ *** Department of Planning and Regional Development \\ University of Thessaly \\ Pedion Areos \\ Volos, 383 34, Greece \\ Tel: +30 2421074451 \\ Fax: +30 2421074380 \\ E-mail: vtselios@prd.uth.gr
}




\title{
Politics and investment: examining the territorial allocation of public investment in Greece
}

\begin{abstract}
This paper discusses how electoral politics shapes the regional allocation of public investment expenditures per capita in Greece. Using regional public investment data for 10 political periods (1975-2009), combined with electoral data by constituency, a model is proposed which captures the influence of politics on the regional distribution of public investment expenditures. The results of the analysis point to a strong relationship between electoral results and regional public investment spending. Greek governing parties have tended to reward those constituencies returning them to office. Moreover, an increase in both the absolute and relative electoral returns of the governing party in a region has traditionally been followed by greater public investment per capita in that region. Regions where the governing party (whether Liberal or Socialist) has held a monopoly of seats have been the greatest beneficiaries of this type of pork-barrel politics.
\end{abstract}

Keywords: public investment, elections, pork-barrel politics, political geography, Greece

JEL classification: H77, H50, R12, R58, Z18 


\section{Política e inversión: análisis de la distribución territorial de la inversión pública en Grecia}

\section{Resumen}

Este artículo examina cómo la política electoral influye en la distribución regional de la inversión pública per cápita en Grecia. El artículo usa datos de inversión pública en diez periodos electorales (1975-2009) en combinación con datos de resultados electorales por circunscripción y propone un modelo para capturar la influencia de la política en la distribución del gasto público. El análisis pone de manifiesto la estrecha relación entre los resultados electorales y el gasto público. Los partidos políticos griegos han tendido a beneficiar aquellas circunscripciones que les han elevado al gobierno. Un aumento de los votos, tanto en términos absolutos como relativos, del partido en el gobierno en una determinada región se ha visto generalmente compensada con una mayor inversión pública per cápita en dicha región. Las regiones en las que el partido gobernante (independientemente de si se trata del Partido Liberal o el Socialista) ha mantenido un monopolio de escaños han sido las mayores beneficiarias de este tipo de política de corte electoralista.

Palabras clave: inversión pública, elecciones, política electoralista, geografía política, Grecia

Clasificación JEL: H77, H50, R12, R58, Z18 


\section{INTRODUCTION}

Public finance theory has argued that public sector intervention in the economy is primarily motivated by the principles of efficient allocation of resources, equal distribution of wealth, and stabilization of economic activity over the business cycle (MUSGRAVE, 1959). The assignment of fiscal responsibilities among different tiers of government - if it safeguards higher efficiency and equity in the provision of public goods to citizens (OATES, 1972) should be welfare enhancing. Public investment would thus improve the growth potential of every region within a country and, as a consequence, of the country as a whole (RODRÍGUEZPOSE et al., 2012). However, a growing body of research has questioned this 'benevolent', 'efficient', and 'equitable' role of the state in allocating public investment. Research conducted over the last three decades has frequently demonstrated how political considerations have seriously influenced the allocation of public expenditures to different jurisdictions, often undermining the capacity of public resources to generate greater social welfare (e.g. BESLEY and COATE, 1998; JOHNSTON, 1977; MARGOLIS, 1968).

The political dimension of public investment has featured prominently in theories of distributive politics. Hirschman (1958, p.190) already argued that public investment decisions have been easily the most political of all economic policy decisions taken by governments. This is because of the geographical nature of both politics and investment. As a consequence, the spatial allocation of public resources is always and inevitably political (BIRD, 1994) and 'spatial political factors are often much more crucial than economic or inter-personal ones in determining many decisions in public finance' (BENNETT, 1980, p.5). However, while the political influence on the allocation of public spending across space is well-documented in the literature, less is known about the exact political mechanisms which govern it. 
Taking stock from the distributive politics literature, this paper sets out to test empirically the relationship between electoral results and regional public investment spending in Greece for the period 1975 and 2009. The choice of Greece and time period is non-random. Greece is a country which has a tradition of strong political parties which have dominated the functioning of the political system. The period under study covers the entire phase between the restoration of democracy in 17 November 1974 until the outbreak of the economic crisis in 2009.

The paper explores whether decision over centrally-controlled public investment allocation in Greece had been driven by 'pork-barrel’ politics. More specifically, it addresses four different aims: whether the orientation of the Greek governing party (Liberal or Socialist) made a difference for the geographical allocation of public investments (aim 1); whether the governing party tended to reward those constituencies returning them to office (aim 2); whether the length in government, which is a proxy for political cycle, has mattered for public investments (aim 3); and whether and to what extent, votes for the different political parties in Greece (Liberal, Socialist and minority parties) and for the governing party in a region have been later translated into greater public investment expenditure in a given region (aim 4).

Our analysis intends to make several contributions to the literature on the interface between politics and economic policy. First, it will offer insights from a fiscally-centralised country, where localities and regions are still highly dependent on central state decisions for the provision of funding opportunities for investment. We analyse all government decisions which concern the allocation of centrally-controlled public investment expenditures - the overwhelming majority of all public investment in Greece - to the 51 NUTS 3 regions of the country. Second, we look at political influence on the allocation of funding from both an absolute and relative regional power perspective. We assess how both the percentage of votes and seats political parties have gained in each constituency may later affect the allocation of public funding to a particular region. Third, the analysis is conducted at the NUTS 3 level, 
which is the administrative unit for regionally identifiable public investment expenditures in Greece. In addition, NUTS 3 regions - with the exception of Attiki and Thessaloniki - represent the electoral constituencies for parliamentary elections. This coincidence makes it possible to examine the relationship between public spending and political power. Fourth, as a less developed member of the EU, Greece has received a large amount of support from structural funds, especially since the reform of the Structural Funds in 1989. These funds had the aim of achieving greater economic growth and regional development, but their effectiveness may have been tainted by politics and by politically-driven decisions. Fifth, the electoral system in Greece throughout the period was one of open-list political representation, leading to the formation at least until the outbreak of the 2009 economic crisis - of a relatively stable dual-party political system. The entire period (1975-2009) constitutes a distinctive period for the Greek political system in the process of Europeanization of the country. Public investments along with structural assistance from the EU helped the country to upgrade its infrastructures and advance its productive environment. Finally, from an empirical point of view, the analysis uses a purpose-built dataset matching the territorial allocation of public investment expenditures to electoral results for a 35-year period (1975-2009). The link between politics and public investment is tested by means of an econometric model.

Summing up, the main contributions of the paper relate to an analysis of political factors, after controlling for some economic factors, over a considerable time span and to the analytical methods applied. To the best of our knowledge - and with the partial exception of LAMBRINIDIS et al.(2005) - there is no similar work for Greece, a country where political decisions and pork-barrel have traditionally been considered to undermine its overall economic potential.

The paper is structured in six sections. This introductory section one is followed by section two which examines the literature on politics and public investment. Section three presents a short 
description of the Greek political system. The methodology, variables and model for the analysis are included in section four. Section five unveils the results of the analysis, while section six provides a synopsis of the main research findings and conclusions.

\section{POLITICS AND INVESTMENT}

Political motivations in the allocation of public investment are not at all new in the scientific literature. The question of tactical spending in favour of incumbent parties has been a frequent object of research for economists, political scientists and geographers alike.

This research has tended to use a variety of different approaches and has been concerned with a number of different countries. The United States system has attracted considerable scrutiny. Among the pioneers, WRIGHT (1974) finds that in the USA tactical spending in presidential politics was an important explanatory variable for the distribution of New Deal funds to states. HOLCOMBE and ZARDKOOHI (1981) also demonstrated that political considerations, rather than objective economic criteria, determined the allocation of Federal grants to states. ANDERSON and TOLLISON (1991) went beyond electoral results and considered congressional politics. They found that the relative clout of the state's congressional delegation was a crucial factor behind the allocation of New Deal spending, meaning that public spending went partly to the needy and partly to those with greater political clout. ANSOLABEHERE and SNYDER (2002) have also shown that governing parties skew the distribution of funds in favour of areas that provide them with the strongest electoral support. They argue that parties may choose to target both loyal and swing areas. Finally, PRIMO and SNYDER (2010) examined whether 'strong' political parties within legislatures are one possible solution to the problem of inefficient universalism, a norm under which all legislators seek large projects for their districts that are paid for out of a common pool. 
At the European level, the results of different analysis are not dissimilar. GOLDEN and PICCI (2008) studied the geographic political determinants of the distribution of infrastructure expenditures to the Italian provinces and found that districts with a stronger connection to the national government have been able to secure more infrastructure investments. LIMOSANI and NAVARRA (2001), when considering the self-interests of legislators and incumbent governments in Italy, have argued that the allocation of public funding has fundamentally responded to the re-election strategies of legislators. Similarly, for the case in Spain, CASTELLS and SOLÉ-OLLÉ (2005) have identified how political considerations have played an important role in the regional allocation of infrastructure investment. They argue that the Spanish government has invested more in the regions where electoral productivity was perceived to be higher. This 'politicization' of public expenditure in Spain has been driven by both incumbent national governments (SOLÉ-OLLÉ and SORRIBAS-NAVARRO, 2008) and by the rise in the relative bargaining power of regional parties (GÓMEZ REINO and HERRERO ALCALDE, 2011). France has also not been immune to the role of electoral politics in determining the allocation of transportation infrastructure investment (CADOT et al., 2006). Finally SUITER and O'MALLEY (2014) find that discretionary sports grant spending in Ireland was targeted to a greater degree than would have been expected to the constituency of the minister in charge.

Summing up the research on the topic, it could be said that, overall, there seems to be a relatively pervasive relationship between politics and political strategies to either gain or preserve power and the allocation of public funding. Whether and how governments reward different territories depending of their electoral or political behaviour is related to a series of factors, including which parties different territories vote for and to the perceptions of governing parties about their electoral prospects in a given territory. According to JOHNSTON (1977), governments and political parties regard territories in three different ways according to their 
electoral prospects: (i) 'hopeless areas', where the governing party has a very low level of electoral support and little hope of ever winning such support; (ii) 'safe areas', where the governing party has a high level of popular support and where victory in electoral contests is virtually guaranteed; and (iii) 'marginal areas', where the governing party either has a slight majority in the voting or its opponents have a slight lead over it. Which type of territory benefits the most depends on the approach to 'pork-barrel' that governments and parties adopt. If the government adopts a 'loyal voter' model, governments will allocate public funds to reward core supporters (COX and MCCUBBINS, 1986). By contrast, under a 'swing voter' model hypotheses, 'swing' regions - or 'marginal areas' - will be more important for future political prospects and, therefore, will secure additional funds (DIXIT and LONDREGAN, 1996; LINDBECK and WEIBULL, 1987). Incumbent governments will have to choose between rewarding their own supporters or 'buying-off' votes in marginal regions, depending on their preferences and on the stage and perceptions of the electoral process.

Greece represents a very interesting case to study the politicization of public investment. It is first a country where established political parties to the left and right of the spectrum have traditionally relied on clientelistic networks. It is also a country with an electoral system which may have favoured the development of political networks and pork-barrel type exchanges. Yet there has been very limited engagement with the politicization of the public purse. To the best of our knowledge, only one study (LAMBRINIDIS et al., 2005) has examined the regional allocation of public investment expenditures in Greece. However, LAMBRINIDIS et al. (2005) limited themselves to the study the connection between votes for the governing party and the territorial allocation of infrastructure expenditure over the period 1982 to 1994 . Our study goes well beyond in that it considers the allocation of all public expenditures and its relationship to a host of political factors over a much longer timespan. 


\section{WHY GREECE?}

\section{The political context}

Greece - like other southern European countries, such as Portugal or Spain - has witnessed massive political and social economic transformations in the last five decades. The two most important ones have been transition from dictatorship to democracy and membership of the European Union. The fall of the dictatorship in 1974 led to the creation of the Third Hellenic Republic and ushered one of the most pluralist and progressive periods in modern history. The Greek political panorama soon became a two-party system: the right-wing New Democracy Party (ND), also known as the Liberal Party, and the left-wing Pan-Hellenic Socialist Movement (PASOK), also known as the Socialist Party alternated in government throughout the whole period of analysis (1974-2009). The two main parties garnered the support of the vast majority of the electorate, sometimes jointly amassing in excess of $80 \%$ of the votes cast (LYRINTZIS and NIKOLAKOPOULOS, 2004). The establishment of an electoral system that favoured the party coming first - the so-called 'reinforced proportionality' system which awards extra seats in Parliament to the winning party - delivered stable majorities which enhanced political stability, but also provided plenty of opportunities for graft and clientelism. A system designed to guarantee stable governments also created incentives for the governing party to make sure it came first in national elections, as single-party-governments have been the only outcome of the electoral system in Greece until the outbreak of the 2009 crisis.

Members of Parliament (MPs) were elected with an open-list system and voters could express preferences for party and candidates. In a Parliament of 300 seats, 151 MPs secured an overall majority. Traditionally 288 MPs of the Assembly were elected directly by means of an open list on the basis of constituency votes. The remaining 12 MPs, the 'national deputies' ('Epikrateias'), were elected from closed lists proposed by political parties. The allocation of 
these seats to different parties was proportional to the political power of each party after elections. The 288 MPs where elected in 56 constituencies. 49 out of the 56 constituencies coincide with prefectures - the NUTS 3 geographical level - and these did not change during the period of analysis. The main discrepancies between constituencies and NUTS 3 regions relate to the two biggest cities in the country: Attiki was divided into five electoral regions (Athens A, Athens B, Piraeus A, Piraeus B and Rest of Attiki) and Thessaloniki into two (Thessaloniki A and Thessaloniki B). Electoral constituencies returned MPs in proportion to their population and the number of MPs by constituency could be adjusted in response to changes in population. Athens B was the largest constituency by population, electing 42 MPs (in the 2004 elections). Eight small constituencies elected only one MP each.

In a country with a very centralized administration and with strict voting discipline in Parliament, incumbent governments have always held a monopoly over decision-making on the geographical allocation of public investments. MPs of the governing party have thus acted as the main conveyors of local political interests in Athens. In this paper we pay particular attention to the role of the incumbent government in decisions about the geographical allocation of public investment. Given the prominent role of public funding, it is anticipated that the very centralized administrative structures of the country would make government the key factor behind decisions to allocate public monies to specific regions. However, the mechanisms through which this allocation is realized are still unknown and constitutes the main research question of this paper.

\section{The allocation of public investment}

As mentioned earlier, the distribution of public investment in Greece is highly centralized. Almost $75 \%$ of total public investment expenditure is administered by National Ministries. Of the remaining $25 \%, 10 \%$ is devolved to the regions (prefectures) and $15 \%$ to the municipalities. 
The geographical allocation of public investment is not based on any particular formula, making the geographical distribution of public funding extremely vulnerable to political bargaining.

In our analysis we consider only the percentage of public investment which is regionally identifiable. This represents on average $55 \%$ of the total. Figure 1 shows the mean per-capita public investment expenditure, compared with the mean per-capita GDP and the mean population density in the 51 NUTS 3 regions of the country (1975-2009). This picture portrays a very unequal distribution of public investment, economic development and population density across Greek regions. As can be seen the small, mountainous and remote regions in the centre and north-west of the country have enjoyed a higher level of per capita support. By contrast, the large agglomerations have generally been disadvantaged in per capita terms. However, this does not guarantee that the provision of and access to public goods in smaller areas was higher relative to larger areas. Given that public goods are characterized by common supply and consumption, the costs of providing public goods for densely-populated areas is smaller than that for sparsely-populated regions.

Insert Figure 1 around here

\section{EMPIRICAL SPECIFICATION AND VARIABLES}

To what extent has the geographical distribution of public investment in Greece been dominated by political criteria? We examine the influence of political determinants on the distribution of public investment expenditures using the following simple empirical function:

$$
I N V_{i t}=f\left(P O L_{i t}, C O N_{i t}\right)
$$


where INV is the dependent variable (i.e. total public investment expenditures per capita) in region $i(i=1,2, \ldots, 51)$ at political period $t(t=1,2, \ldots, 10)$; POL is a vector of political variables; and CON is a vector of control variables.

The political periods are determined by the party in office following successive national elections between 17 November 1974 and 4 October 2009. ${ }^{1}$ As discussed, we expect that national elections influenced public investments in Greece, as a result of the direct control of public funding by the national government and national legislators. ND was the governing party in the periods 1975-1977, 1978-1981, 1990-1993, 2004-2007, and 2008-2009 $(t=1,2$, 5, 9, and 10). PASOK was in office during the periods 1982-1985, 1986-1989, 1994-1996, 1997-1999, and 2000-2003 ( $t=3,4,6,7$, and 8). Both parties were in office for 5 political periods. During the period of analysis there were five changes in the governing party (in 1975 from the military junta to ND, in 1982 from ND to PASOK, in 1990 from PASOK to ND, in 1994 from ND to PASOK, and in 2004 from PASOK to ND). There were no changes in governing party in 5 periods (1978-1981 re-election of ND, 1986-1989 re-election of PASOK, 1977-1999 re-election of PASOK, 2000-2003 re-election of PASOK, and 2008-2008 reelection of ND). The length of political periods varies from 737 days (in 2008-2009) to 1745 days (in 1986-1989).

In the empirical model, our dependent variable (INV) is the natural logarithm of total public investment expenditures per capita collected by the Greek Ministry of Development and Competiveness (formerly Ministry of National Economy) by region $i$ and political period $t$. Total public investment expenditures are classic instances of geographically targetable and divisible goods (GOLDEN and PICCI, 2008). More specifically, the dependent variable is the regionally identifiable public investment expenditures at NUTS III level. It has the advantage that it does not take into consideration current expenditures, such as salaries, unemployment benefits or welfare transfers to a fixed number of individual recipients. 
Public investment expenditures refer to monies spent for investment per capita in agriculture, forestry and fishing, manufacturing, energy, mining and handicraft, transport infrastructures, tourism and modern culture, education and research, housing and environment, health and public welfare, water supply and sewage facilities, devolved public expenditures to regions and prefectures, special infrastructure works, miscellaneous and administrative expenditures, and Olympic Games infrastructure projects (RODRÍGUEZ-POSE et al., 2012). These payments include the EU structural assistance to Greece, alongside the national contribution to EU cofinanced projects, as well as projects of purely national interest and funding. Although these funds - which are part of public investment of the country - had the aim of achieving greater regional economic development, their effectiveness may have also been tainted by politics, as a result of the intervention of the central government in the distribution of funds. As such, the dependent variable may capture political influence and pork-barrelling, as these two factors concern the provision of public and collectively consumed goods and services. Although all types of public investment are open to political discretion, it is fair to say the degree of influence may vary between different types of investment. Hence, different governments may have shown different preferences for specific investment types at specific points in time. In particular, some types of investment may have been more open to political discretion (e.g. road infrastructure building), while others (e.g. expenditures in social well-being) may have been less. ${ }^{2}$ Nevertheless, the general perception has been that the whole Greek payments' system has been subject to political manipulation. For example, Greek governments may have moved expenditures away from health and public welfare or from water supply and sewage facilities towards unemployment benefits in order to garner additional votes in pre-election periods. ${ }^{3}$

Our political variables (POL) refer to national elections and aim to capture the regional political influence over public investment expenditure. As has been explained, we are forced to aggregate the political variables for Attika’s and Thessalonika’s electoral districts to the region 
of Attika and Thessalonika, respectively, as spending is measured only at regional level. The political variables include, GovParty, a dummy variable coding whether the governing party was ND or PASOK (base category), ChGovParty, a dummy variable for whether the governing party was re-elected ( $t=2,4,7,8$ and 10$)$ or changed ( $t=1,3,5,6$ and 9) (base category), and Days, the length of a political period (in days). We include GovParty in order to assess whether the orientation of the governing party makes a difference for the geographical allocation of public investment (aim 1); ChGovParty to examine whether political parties (or their politicians) behave in an opportunistic manner and implement policies aimed at maximising their chances of re-election (ARULAMPALAM et al., 2009) (aim 2); and Days in order to determine whether length in government, which is a proxy for political cycle, matters (aim 3).

The political variables also include regional political power, based on data for the percentage of votes and seats (MPs) in each region, in order to capture the regional influence coming from the strength of political parties, as well as from powerful regional politicians in Parliament. With this variable we intend to assess the extent to which the electoral returns of the different political parties in Greece and of the governing party in a region have been later transformed into greater public investment expenditure (aim 4). We expect that the political variables constructed from data relating to the percentage of votes reflect the strength of political parties, while those based on percentage seat data, the political muscle of local politicians.

The notation, description and meaning (proxy) of the regional political power variables are presented in Table 1. We examine the regional political power of the Liberal Party, the Socialist Party, the minority parties as well as the absolute and the relative political power of the governing party. ${ }^{4}$ In the analysis, we also consider a potential nonlinearity in the correlation of these regional political power variables on public investment expenditures. In other words, we explore possible differences in the magnitude of the political influence between different types 
of political power in regions from different perspectives (e.g. the perspective of the Liberal Party, the Socialist Party, the minority parties and the party holding government). ${ }^{5}$ More specifically, using data on the percentage of votes, we classify regions into three types: 'safe' (i.e. 'high' regional power of the Liberal Party or the Socialist Party and the governing party, and 'high positive' regional power of the governing party relative to the main opposition party), 'marginal' or 'swing' (i.e. 'medium' regional power of the Liberal Party or the Socialist Party and the governing party, and 'low negative or low positive' regional power of the governing party relative to the main opposition party), and 'unsafe' or 'hopeless' (i.e. 'low' regional power of the Liberal Party or the Socialist Party and the governing party, and 'high negative' regional power of the governing party relative to the main opposition party). When using data on the percentage of seats, we classify regions into five, rather than three, types. This is, because the 'safe' regions are classified into 'high' and 'monopolistic' (i.e. 'high' or 'monopolistic' regional power of the Liberal Party or the Socialist Party and the governing party) and the 'unsafe' or 'hopeless' regions are classified into 'low' and 'no power' (i.e. 'low' or 'zero' regional power of the Liberal Party or the Socialist Party and the governing party). The fifth category is the 'marginal' or 'swing' regions (i.e. equal power between the Liberal and the Socialist Party). Finally, we also examine whether single-seat regions were the object of greater 'pork-barrel politics', as swings in these regions would bring greater electoral rewards than in multi-seat regions.

As discussed earlier, we have no a priori hypothesis with respect to the attitude of different Greek political parties - and, consequently, to the attitude of the governing party - to the allocation of investment to different types of regions. Pork-barrel is not inherently a right- or left-wing practice. Under a 'swing voter' model, Greek parties may have pursued a strategy to win over new voters or shift established voting intentions, meaning that the focus of their porkbarrel politics may have been 'marginal’ regions (CUTTS and WEBBER, 2010). Such a model 
would have been followed in the expectation that 'swing' areas would be more responsive than 'safe' areas to distributive benefits and that small changes in voting patterns in these areas would deliver greater numbers of MPs to the detriment of the opposition (DIXIT and LONDREGAN, 1996; LINDBECK and WEIBULL, 1987). Alternatively (or even simultaneously), governing parties may have invested more in areas where they already enjoyed a strong support, leaving swing areas as a secondary target (COX and MCCUBBINS, 1986). By contrast, we do not expect that any governing party in Greece would be particularly concerned with 'hopeless' regions in which their support is low. Therefore, our study also provides an empirical assessment of whether public investments in Greece between 1975 and 2009 went to areas of governing party strength, to areas of opposition party strength, or to contested areas. In other words, we are able to examine whether incumbent governments tended to channel the allocation of intergovernmental transfers to regions with competitive elections or to those where the incumbent party performed better in national elections (SIMÓNCOSANO et al., 2012).

\section{Insert Table 1 around here}

The control variables (CON) include both time-variant region-specific characteristics (GDP per capita as a measure of regional economic development, Density as a proxy for regional agglomeration, and Earthquakes, ${ }^{6}$ a dummy variable coding earthquakes with victims or casualties), as well as time-invariant region-specific characteristics (Size of the region). ${ }^{7}$ The empirical specification also includes political-period-dummies to control for all politicalperiod-specific spatial-invariant variables including the business cycle (RODRÍGUEZ-POSE et al., 2012).

Table 2 presents the abbreviations, definitions and descriptive statistics for all the variables presented above. The dataset is balanced [510 (51x10) observations for all variables] reducing 
potential heterogeneity bias (RODRÍGUEZ-POSE and TSELIOS, 2009). For the whole period, the average percentage of votes and seats in favour of the Liberal Party in a standard region were higher than those of the Socialist Party. Both the minimum and the maximum value of the percentage of votes in the region in favour of the governing party are the minimum and the maximum value, respectively, of the percentage of votes in the region in favour of the Liberal Party. The descriptive statistics also show that the absolute and the relative regional political power of the governing party was considerably higher if we consider the percentage of seats, rather than the percentage of votes. The percentage of votes in any given region in favour of the governing party was on average 46.44 of the total, while the percentage of seats was 61.57 ; and the difference in the percentage of votes in the region in favour of the governing party was 9.09, while the respective difference in the percentage of seats was 27.26.

\section{Insert Table 2 around here}

The correlations between the GovParty, ChGovParty and Days political variables and all control variables (GDP per capita, Density, Earthquakes and Size) are low. However, the correlations between the regional political power variables are high. ${ }^{8}$ This does not allow us to examine the influence of all political power variables on public investment expenditures per capita simultaneously. ${ }^{9}$

\section{REGRESSION RESULTS}

This section presents the regression results of the political determinants of the distribution of total public investment expenditures per capita by the Greek government to the country’s 51 prefectures for the 10 political periods considered. Table 3 depicts the influence of regional political power based on the percentage of votes on public investment expenditures per capita, 
while Table 4 presents the influence of regional political power based on the percentage of seat. Both tables show that public investment expenditures per capita were higher when: a) the governing party was the Liberal Party; b) the governing party had been re-elected; and c) the length of the political period was longer. However, despite the low pairwise correlations between these three political variables (i.e. GovParty, ChGovParty and Days), findings for a) and c) are sensitive to the inclusion or exclusion of the ChGovParty and Days variables, and GovParty and Days variables, respectively (see Appendix 1). There is, therefore, no robust evidence that the orientation of the party in government (Liberal or Socialist) made a difference for the geographical allocation of public investments (aim 1). We also find no proof that the length in government affected the territorial allocation of public investments (aim 3). Consequently, only the finding that public investment expenditures per capita were higher when the governing party had been re-elected is robust to the inclusion of GovParty and Days variables (aim 2). This may indicate that re-elected governments implemented more expansionary policies than newly elected governments, leading to less prudent budgets and probably higher fiscal imbalances. Hence, it seems that governing parties in Greece have tended to reward those constituencies returning them to office. Tables 3 and 4 also show that the coefficient on regional economic development (GDP per capita) is not statistically significant. These results indicate that the allocation of public investment did not follow a criterion of economic need - the regions with lower levels of GDP per head did not receive greater investment per capita. The coefficients on the size of the region and on regional population density are negative and statistically significant, meaning that, as expected, there was greater investment per head in smaller, more remote, and low-density regions, where the cost of delivering public goods and services per head is higher. Finally, the impact of earthquakes on public investment expenditures is not significant.

Insert Table 3 around here 
We then examine whether, and to what extent, votes for the different political parties in Greece and for the governing party in a region are translated into territorial benefits in terms of greater public investment expenditure (aim 4).

Turning to our variables of regional political power based on the percentage of votes, Table 3 reveals that the coefficients on the percentage of votes in the region in favour of each political party (the Liberal Party, the Socialist Party, and the minority parties) are statistically insignificant (Regressions 1, 3 and 5). However, when the dependent variable excludes expenditures in social well-being, the coefficient on the regional political power of the Liberal Party is positive and statistically significant. ${ }^{10}$ Hence, there seems to be no robust evidence that the regional power of the political parties, regardless of the governing party, affected the allocation of public investment expenditures in Greece. When we break down regional political power into 'low', 'medium' and 'high' value, the regression results also do not show evidence for non-linear effects (Regression 2, 4 and 6). Political parties in Greece, at least when considering the percentage of votes to each party, do not seem to have been inclined to invest more in 'safer' constituencies, that is those providing the majority of their votes.

When looking at the influence of the regional political power of the governing party (Regressions 7-10), the results vary significantly. The regression coefficients indicate that both the absolute and the relative political power of the governing party influenced the allocation of public investment expenditures (Regressions 7 and 9, respectively). These relationships are positive and statistically significant. However, the results do not show that there were differences in the absolute and relative regional political power of the governing party between 'safe', 'marginal' and 'unsafe' regions (Regressions 8 and 10, respectively). We have further explored this by examining the absolute and the relative regional political power of the governing party by political party (ND versus PASOK) and by change/no-change in government (change in government versus re-election of government) using interaction effects 
(see Appendix 2). While there is no evidence of difference in the absolute and the relative regional political power of the governing party by political orientation (as the findings are sensitive to the exclusion of expenditures in social well-being) (Regressions 1-8 of Appendix 2), there is evidence that 'pork-barrelling' was more relevant after governing parties had been re-elected (Regressions 9 and 11 of Appendix 2). This comes as no surprise, taking into account our findings for aim 2.

Overall, we observe that, in Greece, 'pork-barrel' investments were, as expected, not a prerogative of the right or of the left, but of the incumbent, and especially re-elected, government. Both ND and PASOK channelled public investment to those regions which returned them to office regardless of ideology. Greek governments and legislators did not feel particularly inclined to reward regions that voted mainly for the opposition or for smaller parties outside the mainstream. Hence, 'pork-barrel' funding during the period of analysis in Greece was limited to safe areas voting for the incumbent government and to those areas where the gap between votes for the governing party and the opposition was higher.

\section{Insert Table 4 around here}

Turning to the regional political power based on the percentage of seats, Table 4 displays no evidence of a linear influence of the political power of the Liberal Party, the Socialist Party, or the minority parties (Regressions 1, 3 and 5, respectively). This conforms to the results reported in Table 3 based on data on the percentage of votes. However, the results in Table 4 (in contrast to Table 3) show evidence of non-linearity in the political power influence of the two main parties in Greece over the territorial allocation of public funds (Regressions 2 and 4). More specifically, regions where ND or PASOK held the same number of seats (base category) received less public investment per head than regions where either of the main parties held a monopoly of seats or no seats at all. This means that over the period of analysis significant 
amounts of additional public funding were channelled to those regions that represented the electoral fiefs of either of the dominant parties in terms of MPs returned. Public investments in Greece between 1975 and 2009 went to areas of monopolistic power of either ND or PASOK. Incumbent parties thus rewarded 'loyal' areas when in office, and, in a country that witnessed a regular changes in the governing party, the perils of supporting the opposition during any given period, were more than compensated by additional transfers when the party supported in the region was in office. Both Table 3 and 4 do not show either linear or non-linear connection of the regional political power of the minority parties with the allocation of public funds (Regression 6). ${ }^{11}$ This is hardly surprising, as MPs from these parties did not have any real influence on the allocation of public funds.

Both analyses based on the percentage of votes (Table 3) and on the percentage of seats (Table 4), indicate that the absolute and the relative political power of the governing party played important roles in the allocation of public investment expenditures per capita in Greece (Regressions 7 and 9, respectively). However, the findings show that the positive association between the political power of the governing party within a region and the public investment expenditures is that region was higher in regions at the extreme of the spectrum in terms of political power. Regions where either of the main parties (ND or PASOK) had a firm grip of the electorate and held a monopoly of the MPs were rewarded. By contrast, 'swing' regions which had a more or less even split in votes and MPs returned between the two main parties ended up being disadvantaged in terms of public expenditure over the period of analysis (Regressions 8 and 10). We have also further explored this by examining the absolute and the relative regional political power of the governing party, based on the percentage of seats, by political party and by change/no-change in government (see Appendix 3). The results do not show great and robust differences by political orientation or by change in government. 
Table 5 shows that almost 58 per cent of such areas were single-seat regions. Indeed, singleseat regions emerge as some of the main destinations of 'pork barrel'. Public investment during the period of analysis was about 56 per cent higher in single-seat regions than in multiple-seat regions (Table 4, Regression 11), with no differences in behaviour for these regions between ND and PASOK when in office (Regression 12).

\section{Insert Table 5 around here}

\section{CONCLUSIONS}

This paper has analysed the influence of political determinants on the distribution of public investment expenditures per capita by the Greek government to the country’s 51 regions over the period 1975-2009. Regional political power was captured using data on the percentage of votes each party received in 10 successive elections, as well as data on the share of MPs for each party returned from each constituency.

The results of the analysis have demonstrated the important role politics has played in the geographical distribution of public investment in Greece. In the 34 years before the outbreak of the crisis, public expenditure was closely correlated with electoral results. The two main Greek political parties when in office followed a 'loyal' voter model to the detriment of a 'swing' voter model: they rewarded those territories that returned them to office, rather than favouring marginal territories which may have brought them more votes and seats in future elections. These findings stand both for the absolute and relative power of the governing party. When in office, the two main parties showered funds to those regions which a) delivered the greatest number of votes and MPs and b) where the distance between them and the main opposition party was greatest. There is, by contrast, no evidence that areas of opposition party 
strength (i.e. 'hopeless' areas for the governing party) or contested areas (i.e. 'marginal' or 'swing' regions) benefited in any way from pork-barrel politics. In general pork-barrel investments ended up in regions where the two main parties had a strong grip and often monopolised the number of deputies returned. Single-seat-constituencies were the main beneficiaries of the system and received significantly higher shares of public investment per capita relative to multi-seat regions. Finally, pork-barrel was reinforced after the re-election of an incumbent government. Changes in the political orientation of the government after national elections resulted in a decline of the political allocation of public investment.

Overall, the analysis points to the importance of politics for the geographical allocation of public investment per capita in Greece. Our results highlight that there is little evidence that public investment has followed criteria aimed at reducing the pervasive territorial inequalities in the country, but plenty more of political meddling and pork-barrel. The strong political polarisation in a country with relatively weak institutions and the political rewards associated with an electoral system aimed at securing political stability left the two main political parties in the country with a significant room to reward those territories that returned them to office.

However, our analysis only scratches the surface of the problem. It provides evidence that party strength and elected representatives have been instrumental in a politically-biased allocation of public funding in Greece, but it says little about the exact mechanisms through which this porkbarrel took place. There is therefore considerable room for further - mainly qualitative research regarding the ways through which the influence of politics in the territorial allocation of public investment has been implemented in Greece. In particular, the role of political representatives, members of Parliament, ministers, and other decision-makers needs to be scrutinised in detail. 


\section{References}

ANDERSON G. M. and TOLLISON R. D. (1991) Congressional influence and patterns of new deal spending, 1933-1939, Journal of Law \& Economics 34, 161-75.

ANSOLABEHERE S. and SNYDER J. M. (2002) The incumbency advantage in U.S. elections: an analysis of state and federal offices, 1942-2000, Election Law Journal: Rules, Politics, and Policy 1, 315-38.

ARULAMPALAM W., DASGUPTA S., DHILLON A. and DUTTA B. (2009) Electoral goals and center-state transfers: A theoretical model and empirical evidence from India, Journal of Development Economics 88, 103-19.

BENNETT R. J. (1980) The geography of public finance: welfare under fiscal federalism and local government finance. Methuen, New York.

BESLEY T. and COATE S. (1998) Sources of inefficiency in a representative democracy: a dynamic analysis, American Economic Review 88, 139-56.

BIRD R. M. (1994) A comparative perspective of federal finance, in BANTING K. G. and BROWN D. M. (Eds) The future of fiscal federalism School of Policy Studies, McGill-Queen's University Press, Kingston, Ontario.

CADOT O., ROLLER L. H. and STEPHAN A. (2006) Contribution to productivity or pork barrel? the two faces of infrastructure investment, Journal of Public Economics 90, 1133-53.

CASTELLS A. and SOLÉ-OLLÉ A. (2005) The regional allocation of infrastructure investment: the role of equity, efficiency and political factors, European Economic Review 49, 1165-205.

COX G. W. and MCCUBBINS M. D. (1986) Electoral politics as a redistributive game, Journal of Politics 48, 370-89.

CUTTS D. and WEBBER D. J. (2010) Voting patterns, party spending and relative location in England and Wales, Regional Studies 44, 735-60. 
DIXIT A. and LONDREGAN J. (1996) The determinants of success of special interests in redistributive politics, Journal of Politics 58, 1132-55.

GOLDEN M. A. and PICCI L. (2008) Pork-barrel politics in postwar Italy, 1953-94, American Journal of Political Science 52, 268-89.

GÓMEZ REINO J. L. and HERRERO ALCALDE A. (2011) Political determinants of regional financing: the case of Spain, Environment and Planning C-Government and Policy 29, 802-20. HIRSCHMAN A. O. (1958) The Strategy of Economic Development. Yale University Press, New Haven.

HOLCOMBE R. G. and ZARDKOOHI A. (1981) The determinants of federal grants, Southern Economic Journal 48, 393-9.

JOHNSTON R. J. (1977) Environment, elections and expenditure: analyses of where governments spend, Regional Studies 11, 383-94.

LAMBRINIDIS M., PSYCHARIS Y. and ROVOLIS A. (2005) Regional allocation of public infrastructure investment: the case of Greece, Regional Studies 39, 1231-44.

LIMOSANI M. and NAVARRA P. (2001) Local pork-barrel politics in national pre-election dates: The case of Italy, Public Choice 106, 317-26.

LINDBECK A. and WEIBULL J. W. (1987) Balanced-budget redistribution as the outcome of political competition, Public Choice 52, 273-97.

LYRINTZIS C. and NIKOLAKOPOULOS H. (2004) The political system and elections in Greece. in About Greece, special volume published by the Greek Ministry of Press and Mass media, second edition, Athens 2004.

MARGOLIS J. (1968) The demand for urban services, in PERLOFF H. S. and WINGO L. (Eds) Issues in Urban Economics. John Hopkins University Press, Baltimore.

MUSGRAVE R. A. (1959) The theory of public finance. McGraw Hill, New York. OATES W. E. (1972) Fiscal federalism. Harcourt Brace Jovanovich, New York. 
PRIMO D. M. and SNYDER J. M., JR. (2010) Party Strength, the Personal Vote, and Government Spending, American Journal of Political Science 54, 354-70.

RODRÍGUEZ-POSE A., PSYCHARIS Y. and TSELIOS V. (2012) Public investment and regional growth and convergence: Evidence from Greece, Papers in Regional Science 91, 54368.

RODRÍGUEZ-POSE A. and TSELIOS V. (2009) Education and income inequality in the regions of the European Union, Journal of Regional Science 49, 411-37.

RODRÍGUEZ-POSE A. and TSELIOS V. (2011) Mapping the European regional educational distribution, European Urban and Regional Studies 18, 358-74.

SIMÓN-COSANO P., LAGO-PEÑAS S. and VAQUERO A. (2012) On the political determinants of intergovernmental grants in decentralized countries: the case of Spain. Working Paper 12-30, September 2012, International Centre for Public Policy, Georgia State University.

SOLÉ-OLLÉ A. and SORRIBAS-NAVARRO P. (2008) The effects of partisan alignment on the allocation of intergovernmental transfers. Differences-in-differences estimates for Spain, Journal of Public Economics 92, 2302-19.

SUITER J. and O'MALLEY E. (2014) Chieftains delivering: Testing different measures of 'pork' on an Irish data set of discretionary sports grants Journal of Elections, Public Opinion and Parties 24, 115-24.

TSELIOS V., RODRÍGUEZ-POSE A., PIKE A., TOMANEY J. and TORRISI G. (2012) Income inequality, decentralisation, and regional development in Western Europe, Environment and Planning A 44, 1278-301.

WRIGHT G. (1974) Political economy of new deal spending: econometric analysis, Review of Economics and Statistics 56, 30-8. 
Table 1: Regional political power variables

\begin{tabular}{|c|c|c|}
\hline NOTATION & DESCRIPTION & MEANING \\
\hline \multicolumn{3}{|l|}{ VOTES } \\
\hline$\%$ ND - Votes & $\begin{array}{l}\text { Percentage votes in the region in favour } \\
\text { of ND }\end{array}$ & Power of the Liberal Party \\
\hline - $\% \mathrm{ND}<30$ & & - Low \\
\hline - $30 \leq \% \mathrm{ND} \leq 50$ & & - Medium \\
\hline - $\% \mathrm{ND}>50$ & & - High \\
\hline \%PASOK - Votes & $\begin{array}{l}\text { Percentage votes in the region in favour } \\
\text { of PASOK }\end{array}$ & Power of the Socialist Party \\
\hline - \%PASOK $<30$ & & - Low \\
\hline - $30 \leq \% \mathrm{PASOK} \leq 50$ & & - Medium \\
\hline - $\%$ PASOK > 50 & & - High \\
\hline \%Rest - Votes & $\begin{array}{l}\text { Percentage votes in the region in favour } \\
\text { of minority parties (e.g. the Greek } \\
\text { Communist(s) Parties) }\end{array}$ & Power of the minority parties \\
\hline - $\%$ Rest $<10$ & & - Low \\
\hline - $10 \leq \%$ Rest $\leq 30$ & & - Medium \\
\hline - $\%$ Rest $>30$ & & - High \\
\hline \%GovParty - Votes & $\begin{array}{l}\text { Percentage votes in the region in favour } \\
\text { of the governing party }\end{array}$ & $\begin{array}{l}\text { Power of the governing party (i.e. } \\
\text { absolute political power of the } \\
\text { governing party) }\end{array}$ \\
\hline - \%GovParty $<30$ & & - Low \\
\hline - $30 \leq \%$ GovParty $\leq 50$ & & - Medium \\
\hline - \%GovParty > 50 & & - High \\
\hline Dif\%GovParty - Votes* & $\begin{array}{l}\text { Difference in the percentage votes in the } \\
\text { region in favour of the governing party }\end{array}$ & $\begin{array}{l}\text { Power of the governing party } \\
\text { relative to the main opposition party } \\
\text { (i.e. relative political power of the } \\
\text { governing party) }\end{array}$ \\
\hline - Dif\%GovParty $<-5$ & & - High negative \\
\hline - $-5 \leq$ Dif\%GovParty $\leq 5$ & & - Low negative or low positive \\
\hline - Dif\%GovParty $>5$ & & - High positive \\
\hline \multicolumn{3}{|l|}{ SEATS } \\
\hline \%ND - Seats & $\begin{array}{l}\text { Percentage seats in the region in favour } \\
\text { of ND }\end{array}$ & Power of the Liberal Party \\
\hline - $\% \mathrm{ND}=0$ & & - No (Zero) \\
\hline - $0<\% \mathrm{ND}<50$ & & - Low \\
\hline - $\% \mathrm{ND}=50$ & & $\begin{array}{l}\text { - Equal power between the } \\
\text { Liberal and the Socialist Party }\end{array}$ \\
\hline - $50<\%$ ND $<100$ & & - High \\
\hline - $\% \mathrm{ND}=100$ & & - Monopolistic \\
\hline \%PASOK - Seats & $\begin{array}{l}\text { Percentage seats in the region in favour } \\
\text { of PASOK }\end{array}$ & Power of the Socialist Party \\
\hline - $\% \mathrm{PASOK}=0$ & & - No (Zero) \\
\hline - $0<\%$ PASOK $<50$ & & - Low \\
\hline - $\%$ PASOK = 50 & & $\begin{array}{l}\text { - Equal power between the } \\
\text { Liberal and the Socialist Party }\end{array}$ \\
\hline - $50<\%$ PASOK $<100$ & & - High \\
\hline - $\%$ PASOK = 100 & & - Monopolistic \\
\hline \%Rest - Seats & $\begin{array}{l}\text { Percentage seats in the region in favour } \\
\text { of minority parties (e.g. the Greek } \\
\text { Communist(s) Parties) }\end{array}$ & Power of the minority parties \\
\hline - $\%$ Rest $<5$ & & - Low \\
\hline - $5 \leq \%$ Rest $\leq 100$ & & - High \\
\hline \%GovParty - Seats & $\begin{array}{l}\text { Percentage seats in the region in favour } \\
\text { of the governing party }\end{array}$ & $\begin{array}{l}\text { Power of the governing party (i.e. } \\
\text { absolute political power of the } \\
\text { governing party) }\end{array}$ \\
\hline - $\%$ GovParty $=0$ & & - No \\
\hline - $0<\%$ GovParty $<50$ & & - Low \\
\hline - $\%$ GovParty $=50$ & & $\begin{array}{l}\text { - Equal power between the } \\
\text { Liberal and the Socialist Party }\end{array}$ \\
\hline - $50<\%$ GovParty $<100$ & & - High \\
\hline - $\%$ GovParty $=100$ & & - Monopolistic \\
\hline
\end{tabular}


Dif\%GovParty - Seats ${ }^{* *}$

- Dif\%GovParty $=-100$

- $-100<$ Dif\%GovParty $<0$

- Dif\%GovParty = 0

- $0<$ Dif\%GovParty $<100$

- Dif\%GovParty = 100

Single-seat region

Single-seat region \& ND

Single-seat region \& PASOK
Difference in the percentage seats in the region in favour of the governing party

Dummy for single-seat regions

Dummy for single-seat regions \& ND is

in office

Dummy for single-seat regions \&

PASOK is in office
Power of the governing party relative to the main opposition party (i.e. relative political power of the governing party)

- No

- Low

- Equal power between the Liberal and the Socialist Party

- High

- Monopolistic

Note: * ‘\%GovParty - Votes (Seats)’ = ‘\%ND - Votes (Seats)’ x ‘GovParty’ + ‘\%PASOK - Votes (Seats)’ x (1 -

'GovParty'); ** ‘Dif\%GovParty - Votes (Seats)' = ('\%ND - Votes (Seats)' - '\%PASOK - Votes (Seats)’) x ‘GovParty’ + ('\%PASOK - Votes (Seats)' - ‘\%ND - Votes (Seats)’) x (1 - ‘GovParty’). 
Table 2: Descriptive statistics

\begin{tabular}{lrrrrr}
\hline Variables & Obs & Mean & Std. Dev. & Min & Max \\
\hline Dependent variable (INV) & & & & & \\
\hline Natural logarithm of public investment expenditures & & & & & \\
per capita & 510 & 12.4381 & 0.5039 & 10.9859 & 14.9242 \\
\hline Political variables (POL) & & & & & \\
\hline GovParty (base: PASOK) & 510 & 0.5000 & 0.5005 & 0 & 1 \\
ChGovParty (base: change) & 510 & 0.5000 & 0.5005 & 0 & 1 \\
Days & 510 & 1254.7000 & 250.2747 & 737 & 1745 \\
\%ND - Votes & 510 & 44.2522 & 8.0279 & 15.2608 & 76.0418 \\
\%PASOK - Votes & 510 & 39.5386 & 10.5010 & 10.8753 & 64.3227 \\
\%Rest - Votes & 510 & 16.2092 & 8.8983 & 0.6593 & 60.5497 \\
\%GovParty - Votes & 510 & 46.4429 & 7.4659 & 15.2608 & 76.0418 \\
Dif\%GovParty - Votes & 510 & 9.0949 & 14.4788 & -22.6513 & 63.1174 \\
\%ND - Seats & 510 & 51.3138 & 25.3594 & 0 & 100 \\
\%PASOK - Seats & 510 & 44.5681 & 24.5064 & 0 & 100 \\
\%Rest - Seats & 510 & 4.1181 & 11.6077 & 0 & 100 \\
\%GovParty - Seats & 510 & 61.5711 & 21.6101 & 0 & 100 \\
Dif\%GovParty - Seats & 510 & 27.2602 & 40.6644 & -100 & 100 \\
Single-seat region (base: multiple-seat region) & 510 & 0.1098 & 0.3130 & 0 & 1 \\
Single-seat region \& ND (base: other regions) & 510 & 0.0569 & 0.2318 & 0 & 1 \\
Single-seat region \& PASOK (base: other regions) & 510 & 0.0529 & 0.2241 & 0 & 1 \\
\hline Control variables (CON) & & & & & \\
\hline GDP per capita (/10,000) & 510 & 0.9985 & 0.3853 & 0.4068 & 3.9618 \\
Size of the region (/10,000) (time-invariant variable) & 510 & 0.2587 & 0.1230 & 0.0356 & 0.5461 \\
Population density & 510 & 0.0724 & 0.1325 & 0.0103 & 1.0946 \\
Earthquakes with victims and casualties & 510 & 0.0098 & 0.0986 & 0 & 1 \\
\hline & & & & & 0 \\
\end{tabular}


Table 3: Regional political power based on percentage votes

\begin{tabular}{|c|c|c|c|c|c|c|c|c|c|c|}
\hline & (1) & (2) & (3) & (4) & (5) & (6) & (7) & (8) & (9) & $(10)$ \\
\hline GovParty: PASOK & base & base & base & base & base & base & base & base & base & base \\
\hline GovParty: ND & $2.1727 * * *$ & $2.1576 * * *$ & $2.0331 * * *$ & $2.4327 * * *$ & $2.0468 * * *$ & $2.1003 * * *$ & $2.3575 * * *$ & $2.1731 * * *$ & $2.5151 * * *$ & $2.1720 * * *$ \\
\hline ChGovParty: Change & base & base & base & base & base & base & base & base & base & base \\
\hline ChGovParty: No change & $1.6871 * * *$ & $1.6742 * * *$ & $1.5701 * * *$ & $1.8926 * * *$ & $1.5880 * * *$ & $1.6268 * * *$ & $1.8491 * * *$ & $1.6882 * * *$ & $1.9733^{* * *}$ & $1.7003^{* * *}$ \\
\hline Days & $0.0031 * * *$ & $0.0031^{* * *}$ & $0.0029 * * *$ & $0.0035 * * *$ & $0.0029 * * *$ & $0.0030 * * *$ & $0.0034 * * *$ & $0.0031 * * *$ & $0.0036 * * *$ & $0.0031 * * *$ \\
\hline \%ND - Votes & 0.0008 & & & & & & & & & \\
\hline - $\% \mathrm{ND}<30$ & & -0.0581 & & & & & & & & \\
\hline - $30 \leq \% \mathrm{ND} \leq 50$ & & base & & & & & & & & \\
\hline - \%ND > 50 & & 0.0074 & & & & & & & & \\
\hline \%PASOK - Votes & & & 0.0019 & & & & & & & \\
\hline • \%PASOK < 30 & & & & 0.0898 & & & & & & \\
\hline - $30 \leq \%$ PASOK $\leq 50$ & & & & base & & & & & & \\
\hline - \%PASOK > 50 & & & & -0.0208 & & & & & & \\
\hline \%Rest - Votes & & & & & -0.0030 & & & & & \\
\hline - \%Rest $<10$ & & & & & & 0.0013 & & & & \\
\hline - $10 \leq \%$ Rest $\leq 30$ & & & & & & base & & & & \\
\hline - \%Rest > 30 & & & & & & -0.1254 & & & & \\
\hline \%GovParty - Votes & & & & & & & $0.0061^{* *}$ & & & \\
\hline - \%GovParty < 30 & & & & & & & & -0.0833 & & \\
\hline - $30 \leq \%$ GovParty $\leq 50$ & & & & & & & & base & & \\
\hline - \%GovParty > 50 & & & & & & & & 0.0159 & & \\
\hline Dif\%GovParty - Votes & & & & & & & & & $0.0035^{*}$ & \\
\hline - Dif\%GovParty <-5 & & & & & & & & & & base \\
\hline - $-5 \leq$ Dif $\%$ GovParty $\leq 5$ & & & & & & & & & & 0.0759 \\
\hline - Dif\%GovParty > 5 & & & & & & & & & & 0.0865 \\
\hline GDP per capita & 0.0578 & 0.0567 & 0.0508 & 0.0615 & 0.0526 & 0.0486 & 0.0491 & 0.0555 & 0.0525 & 0.0504 \\
\hline Size & $-0.7226 * * *$ & $-0.7183 * * *$ & $-0.7046 * * *$ & $-0.7293 * * *$ & $-0.7339 * * *$ & $-0.7404 * * *$ & $-0.7499 * * *$ & $-0.7176 * * *$ & $-0.7321 * * *$ & $-0.7246 * * *$ \\
\hline Density & $-0.4796 * * *$ & $-0.4791 * * *$ & $-0.4847 * * *$ & $-0.4863 * * *$ & $-0.4532 * * *$ & $-0.4748 * * *$ & $-0.4526 * * *$ & $-0.4833^{* * *}$ & $-0.4872 * * *$ & $-0.4992 * * *$ \\
\hline Earthquakes: no & base & base & base & base & base & base & base & base & base & base \\
\hline Earthquakes: yes & 0.2212 & 0.2194 & 0.2212 & 0.2192 & 0.2122 & 0.1921 & 0.2095 & 0.2193 & 0.2202 & 0.2358 \\
\hline Time-dummies & yes & yes & yes & yes & yes & yes & yes & yes & yes & yes \\
\hline Constant & $6.6633^{* * *}$ & $6.7424 * * *$ & $7.0485^{* * *}$ & $5.9399 * * *$ & $7.1326 * * *$ & $6.9315^{* * *}$ & $5.8971 * * *$ & $6.6979 * * *$ & $5.6700 * * *$ & $6.6104 * * *$ \\
\hline Observations & 510 & 510 & 510 & 510 & 510 & 510 & 510 & 510 & 510 & 510 \\
\hline R-squared & 0.2374 & 0.2377 & 0.2378 & 0.2383 & 0.2384 & 0.2399 & 0.2432 & 0.2378 & 0.2429 & 0.2401 \\
\hline
\end{tabular}


Table 4: Regional political power based on percentage seats

\begin{tabular}{|c|c|c|c|c|c|c|c|c|c|c|c|c|}
\hline & (1) & (2) & (3) & (4) & (5) & (6) & (7) & (8) & (9) & (10) & (11) & (12) \\
\hline GovParty: PASOK & base & base & base & base & base & base & base & base & base & base & base & base \\
\hline GovParty: ND & $2.1415^{* * *}$ & $2.5980 * * *$ & $2.1584 * * *$ & $2.5861 * * *$ & $2.1407 * * *$ & $2.1675^{* * *}$ & $2.4167 * * *$ & $2.6377 * * *$ & $2.4401 * * *$ & $2.5971^{* * *}$ & $1.9477^{* * *}$ & $1.9418 * * *$ \\
\hline ChGovParty: Change & base & base & base & base & base & base & base & base & base & base & base & base \\
\hline ChGovParty: No change & $1.6564^{* * *}$ & $2.0209 * * *$ & $1.6757^{* * *}$ & $2.0032 * * *$ & $1.6588 * * *$ & $1.6821 * * *$ & $1.8948 * * *$ & $2.0688 * * *$ & $1.9150 * * *$ & $2.0390 * * *$ & $1.5232 * * *$ & $1.5211^{* * *}$ \\
\hline Days & $0.0030^{* * *}$ & $0.0037 * * *$ & $0.0031^{* * *}$ & $0.0036^{* * *}$ & $0.0031^{* * *}$ & $0.0031^{* * *}$ & $0.0035^{* * *}$ & $0.0038^{* * *}$ & $0.0035^{* * *}$ & $0.0037 * * *$ & $0.0028 * * *$ & $0.0028 * * *$ \\
\hline$\%$ ND - Seats & -0.0002 & & & & & & & & & & & \\
\hline - $\% \mathrm{ND}=0$ & & $0.3568 * * *$ & & & & & & & & & & \\
\hline $\begin{array}{l}\text { - } \quad 0<\% \mathrm{ND}<50 \\
\text { - } \% \mathrm{ND}=50\end{array}$ & & $\begin{array}{l}-0.0876 \\
\text { hase }\end{array}$ & & & & & & & & & & \\
\hline $\begin{array}{ll}\text { - } & \% \mathrm{ND}=50 \\
\text { - } & 50<\% \mathrm{ND}<100\end{array}$ & & $\begin{array}{l}\text { base } \\
-0.0867\end{array}$ & & & & & & & & & & \\
\hline - $\% \mathrm{ND}=100$ & & $0.3357 * * *$ & & & & & & & & & & \\
\hline \%PASOK - Seats & & & -0.0001 & & & & & & & & & \\
\hline - $\% \mathrm{PASOK}=0$ & & & & $0.3055^{* * *}$ & & & & & & & & \\
\hline - $0<\%$ PASOK $<50$ & & & & $-0.1178 * *$ & & & & & & & & \\
\hline - $\%$ PASOK = 50 & & & & base & & & & & & & & \\
\hline - $50<\%$ PASOK $<100$ & & & & -0.0725 & & & & & & & & \\
\hline - $\%$ PASOK = 100 & & & & $0.4134 * * *$ & & & & & & & & \\
\hline \%Rest - Seats & & & & & 0.0011 & & & & & & & \\
\hline - $\quad \%$ Rest $<5$ & & & & & & base & & & & & & \\
\hline - $5 \leq \%$ Rest $\leq 100$ & & & & & & -0.0457 & & & & & & \\
\hline \%GovParty - Seats & & & & & & & $0.0035^{* * *}$ & & & & & \\
\hline - \%GovParty = 0 & & & & & & & & $0.4169 * * *$ & & & & \\
\hline - $0<\%$ GovParty $<50$ & & & & & & & & $-0.1100 *$ & & & & \\
\hline - \%GovParty = 50 & & & & & & & & base & & & & \\
\hline - $50<\%$ GovParty $<100$ & & & & & & & & -0.0382 & & & & \\
\hline • $\%$ GovParty = 100 & & & & & & & & $0.3784 * * *$ & & & & \\
\hline Dif\%GovParty - Seats & & & & & & & & & $0.0020^{* * *}$ & & & \\
\hline - Dif\%GovParty = -100 & & & & & & & & & & $0.4338 * * *$ & & \\
\hline - $-100<$ Dif\%GovParty $<0$ & & & & & & & & & & $-0.1995 * * *$ & & \\
\hline - Dif\%GovParty $=0$ & & & & & & & & & & base & & \\
\hline - $0<$ Dif\%GovParty $<100$ & & & & & & & & & & $-0.1083^{* *}$ & & \\
\hline - Dif\%GovParty = 100 & & & & & & & & & & $0.3282^{* * *}$ & & \\
\hline Other regions & & & & & & & & & & & base & base \\
\hline Single-seat region & & & & & & & & & & & $0.5572 * * *$ & \\
\hline Single-seat region \& ND & & & & & & & & & & & & $0.5686 * * *$ \\
\hline Single-seat region \& PASOK & & & & & & & & & & & & $0.5451 * * *$ \\
\hline GDP per capita & 0.0568 & 0.0390 & 0.0567 & 0.0323 & 0.0597 & 0.0508 & 0.0454 & 0.0332 & 0.0495 & 0.0191 & 0.0505 & 0.0500 \\
\hline Size & $-0.7118 * * *$ & -0.1032 & $-0.7155^{* * *}$ & -0.0651 & $-0.7165 * * *$ & $-0.6728 * * *$ & $-0.5961 * * *$ & -0.1272 & $-0.5806 * * *$ & -0.0883 & -0.1195 & -0.1199 \\
\hline Density & $-0.4912 * * *$ & $-0.3917 * *$ & $-0.4869 * * *$ & $-0.3882 * * *$ & $-0.5057 * * *$ & $-0.4401 * * *$ & $-0.4434 * * *$ & $-0.3693 * *$ & $-0.4700 * * *$ & $-0.3963 * * *$ & $-0.4432 * * *$ & $-0.4429 * * *$ \\
\hline Earthquakes: no & base & base & base & base & base & base & base & base & base & base & base & base \\
\hline Earthquakes: yes & 0.2244 & 0.2737 & 0.2225 & 0.2754 & 0.2236 & 0.2276 & 0.2296 & 0.2711 & 0.2312 & 0.2805 & 0.2365 & 0.2362 \\
\hline Time-dummies & yes & yes & yes & yes & yes & yes & yes & yes & yes & yes & yes & yes \\
\hline Constant & $6.8099 * * *$ & $5.3597 * * *$ & $6.7404^{* * *}$ & $5.4520 * * *$ & $6.7793^{* * *}$ & $6.7277 * * *$ & $5.7455^{* * *}$ & $5.2038 * * *$ & $5.8125^{* * *}$ & $5.3570^{* * *}$ & $7.0768 * * *$ & $7.0870^{* * *}$ \\
\hline Observations & 510 & 510 & 510 & 510 & 510 & 510 & 510 & 510 & 510 & 510 & 510 & 510 \\
\hline R-squared & 0.2374 & 0.3113 & 0.2373 & 0.3144 & 0.2378 & 0.2382 & 0.2551 & 0.3133 & 0.2592 & 0.3173 & 0.3344 & 0.3344 \\
\hline
\end{tabular}


Table 5: Single-seat and non-one seat regions with monopolistic power and no power in favour of the governing party

\begin{tabular}{|c|c|c|c|c|c|c|}
\hline \multirow{5}{*}{$\begin{array}{l}\text { Multiple-seat region } \\
\text { Single-seat region } \\
\text { Total }\end{array}$} & \multicolumn{4}{|c|}{$\begin{array}{l}\% \text { GovParty }- \text { Seats } \\
\text { max }=100 \\
\text { (monopolistic power) }\end{array}$} & \multicolumn{2}{|c|}{$\min$ or $\max$} \\
\hline & Freq. & Percent & Freq & Percent & Freq. & Percent \\
\hline & $1^{\dagger}$ & 8.33 & 33 & 42.31 & 34 & 37.78 \\
\hline & $11^{+\dagger}$ & 91.67 & 45 & 57.69 & 56 & 62.22 \\
\hline & 12 & 100 & 78 & 100 & 90 & 100 \\
\hline & \multicolumn{4}{|c|}{$\begin{array}{c}\text { Dif\%GovParty }- \text { Seats } \\
\max =100 \\
\text { (monopolistic power) }\end{array}$} & \multicolumn{2}{|c|}{$\min$ or $\max$} \\
\hline & Freq & Rercent & Freq & Percent & Freq & Percent \\
\hline Multiple-seat region & 0 & 0 & 33 & 42.31 & 33 & 38.82 \\
\hline Single-seat region & 7 & 100 & 45 & 57.69 & 52 & 61.18 \\
\hline Total & 7 & 100 & 78 & 100 & 85 & 100 \\
\hline
\end{tabular}


Figure 1: Regional distribution of public investment expenditures per capita, GDP per capita and population density
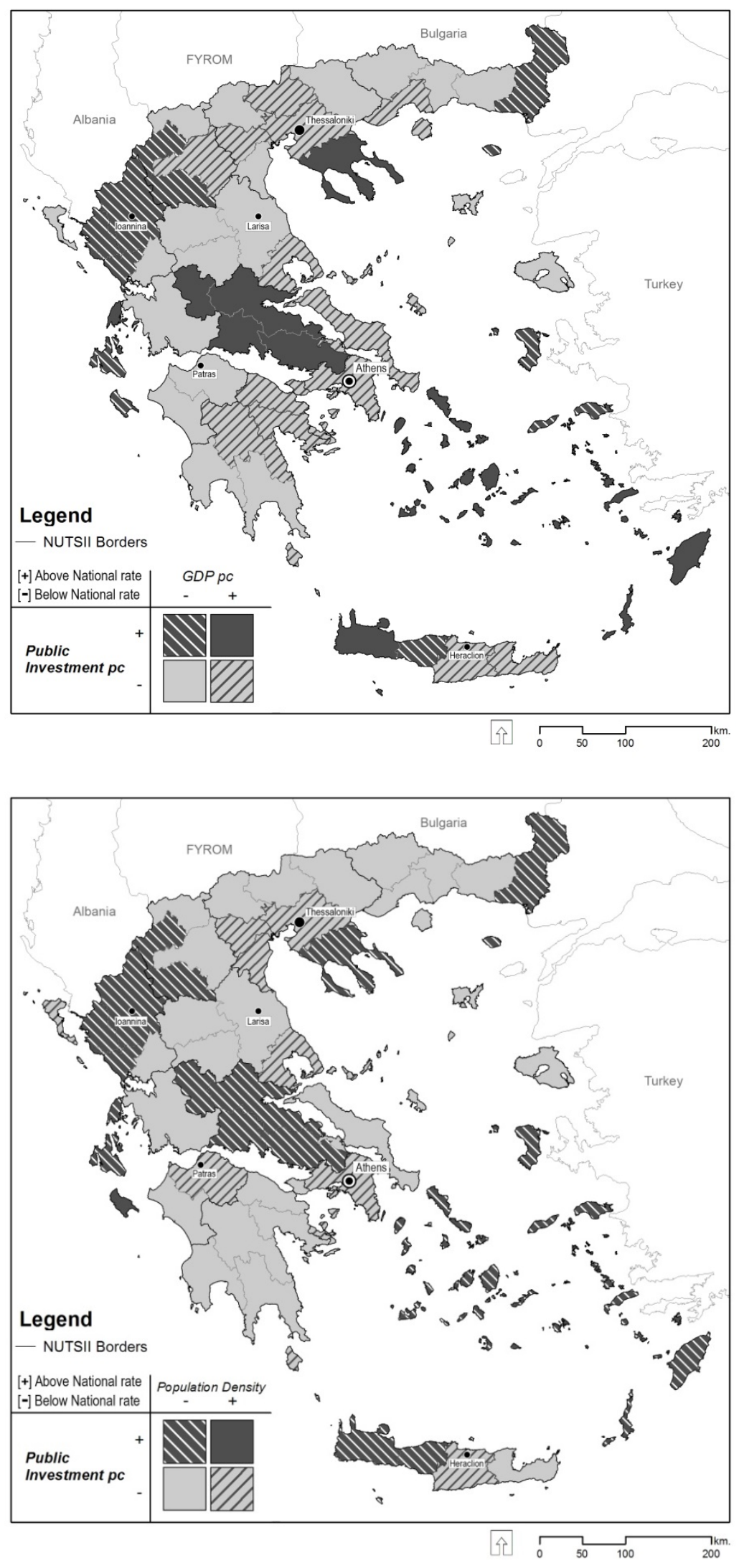


\section{Appendix 1: Sensitivity of the GovParty, ChGovParty and Days variables}

\begin{tabular}{|c|c|c|c|c|c|c|c|}
\hline & $(1)$ & (2) & (3) & (4) & (5) & (6) & $(7)$ \\
\hline GovParty: PASOK & base & & & base & base & & base \\
\hline GovParty: ND & $-0.5131 * * *$ & & & 0.0976 & $-1.0884 * * *$ & & $2.1527 * * *$ \\
\hline ChGovParty: Change & & base & & base & & base & base \\
\hline ChGovParty: No change & & $0.6107 * * *$ & & $0.6107 * * *$ & & $1.6689 * * *$ & $1.6689 * * *$ \\
\hline Days & & & $-0.0018 * * *$ & & $-0.0018 * * *$ & $0.0031 * * *$ & $0.0031 * * *$ \\
\hline GDP per capita & 0.0565 & 0.0565 & 0.0565 & 0.0565 & 0.0565 & 0.0565 & 0.0565 \\
\hline Size & $-0.7139 * * *$ & $-0.7139 * * *$ & $-0.7139 * * *$ & $-0.7139 * * *$ & $-0.7139 * * *$ & $-0.7139 * * *$ & $-0.7139 * * *$ \\
\hline Density & $-0.4872 * * *$ & $-0.4872 * * *$ & $-0.4872 * * *$ & $-0.4872 * * *$ & $-0.4872 * * *$ & $-0.4872 * * *$ & $-0.4872 * * *$ \\
\hline Earthquakes: no & base & base & base & base & base & base & base \\
\hline Earthquakes: yes & 0.2232 & 0.2232 & 0.2232 & 0.2232 & 0.2232 & 0.2232 & 0.2232 \\
\hline Time-dummies & yes & yes & yes & yes & yes & yes & yes \\
\hline Constant & $12.7427 * * *$ & $12.2296 * * *$ & $14.1449 * * *$ & $12.1320 * * *$ & $15.2333 * * *$ & $8.9108 * * *$ & $6.7581 * * *$ \\
\hline Observations & 510 & 510 & 510 & 510 & 510 & 510 & 510 \\
\hline R-squared & 0.2373 & 0.2373 & 0.2373 & 0.2373 & 0.2373 & 0.2373 & 0.2373 \\
\hline
\end{tabular}


Appendix 2: Regional political power of the governing party based on the percentage votes by political party and by change/non-change in government

\begin{tabular}{|c|c|c|c|c|c|c|c|c|c|c|c|c|}
\hline & & & & & Exclu & ling social we & -being expens & tures & & & & \\
\hline & (1) & (2) & (3) & (4) & (5) & $(6)$ & $(7)$ & $(8)$ & $(9)$ & (10) & (11) & $(12)$ \\
\hline GovParty: PASOK & base & base & base & base & base & base & base & base & base & base & base & base \\
\hline GovParty: ND & $2.3293^{* * *}$ & $2.2242^{* * *}$ & $2.4673^{* * *}$ & $2.2010 * * *$ & $2.8520 * * *$ & $3.1603 * * *$ & $3.6553 * * *$ & $2.9890 * * *$ & $2.3033^{* * *}$ & $2.0986 * * *$ & $2.3369 * * *$ & $2.0745 * * *$ \\
\hline ChGovParty: Change & base & base & base & base & base & base & base & base & base & base & base & base \\
\hline ChGovParty: No change & $1.8555^{* * *}$ & $1.7441^{* * *}$ & $1.9326 * * *$ & $1.6636^{* * *}$ & $2.6691^{* * *}$ & $2.4912^{* * *}$ & $2.8730 * * *$ & $2.3620 * * *$ & $1.5980^{* * *}$ & $1.6173^{* * *}$ & $1.8204^{* * *}$ & $1.5341^{* * *}$ \\
\hline Days & $0.0034 * * *$ & $0.0032 * * *$ & $0.0036^{* * *}$ & $0.0031 * * *$ & $0.0050 * * *$ & $0.0046 * * *$ & $0.0054 * * *$ & $0.0044 * * *$ & $0.0033 * * *$ & $0.0030 * * *$ & $0.0034 * * *$ & $0.0030 * * *$ \\
\hline \%GovParty - Votes x ND & 0.0064 & & & & $0.0123 * * *$ & & & & & & & \\
\hline \%GovParty - Votes x PASOK & 0.0056 & & & & 0.0001 & & & & & & & \\
\hline - \%GovParty < 30 x ND & & -0.0689 & & & & -0.2278 & & & & & & \\
\hline - $30 \leq \%$ GovParty $\leq 50 \times$ ND & & base & & & & base & & & & & & \\
\hline - \%GovParty > 50 x ND & & 0.0535 & & & & 0.1121 & & & & & & \\
\hline - $30 \leq \%$ GovParty $\leq 50 \times$ PASOK & & base & & & & base & & & & & & \\
\hline - \%GovParty > 50 x PASOK & & -0.0236 & & & & -0.0924 & & & & & & \\
\hline Dif\%GovParty - Votes x ND & & & 0.0030 & & & & $0.0065 * *$ & & & & & \\
\hline Dif\%GovParty - Votes x PASOK & & & 0.0042 & & & & 0.0006 & & & & & \\
\hline - Dif\%GovParty < -5 x ND & & & & base & & & & base & & & & \\
\hline - $-5 \leq$ Dif $\%$ GovParty $\leq 5 \times$ ND & & & & 0.0540 & & & & 0.1577 & & & & \\
\hline - Dif\%GovParty > 5 x ND & & & & 0.0142 & & & & 0.1380 & & & & \\
\hline - Dif\%GovParty $<-5$ x PASOK & & & & base & & & & base & & & & \\
\hline - $-5 \leq$ Dif\%GovParty $\leq 5 \times$ PASOK & & & & 0.0984 & & & & 0.1034 & & & & \\
\hline - Dif\%GovParty > 5 x PASOK & & & & $0.1486 *$ & & & & 0.0977 & & & & \\
\hline \%GovParty - Votes x NO CHA & & & & & & & & & $0.0088 *$ & & & \\
\hline \%GovParty - Votes x CHANGE & & & & & & & & & 0.0042 & & & \\
\hline • \%GovParty < 30 x NO CHA & & & & & & & & & & 0.0106 & & \\
\hline - $30 \leq \%$ GovParty $\leq 50 \times$ NO CHA & & & & & & & & & & base & & \\
\hline - \%GovParty > 50 x NO CHA & & & & & & & & & & 0.0520 & & \\
\hline - \%GovParty < 30 x CHANGE & & & & & & & & & & -0.2737 & & \\
\hline - $30 \leq \%$ GovParty $\leq 50 \times$ CHANGE & & & & & & & & & & base & & \\
\hline - \%GovParty > 50 x CHANGE & & & & & & & & & & -0.0098 & & \\
\hline Dif\%GovParty - Votes x NO CHA & & & & & & & & & & & $0.0058 * *$ & \\
\hline Dif\%GovParty - Votes x CHANGE & & & & & & & & & & & 0.0019 & \\
\hline - Dif\%GovParty < -5 x NO CHA & & & & & & & & & & & & base \\
\hline - $-5 \leq$ Dif\%GovParty $\leq 5 \times$ NO CHA & & & & & & & & & & & & 0.0939 \\
\hline - Dif\%GovParty $>5$ x NO CHA & & & & & & & & & & & & $0.1647^{*}$ \\
\hline - Dif\%GovParty $<-5$ x CHANGE & & & & & & & & & & & & base \\
\hline - $-5 \leq$ Dif\%GovParty $\leq 5 \times$ CHANGE & & & & & & & & & & & & 0.0472 \\
\hline - Dif\%GovParty > 5 x CHANGE & & & & & & & & & & & & 0.0013 \\
\hline GDP per capita & 0.0502 & 0.0602 & 0.0497 & 0.0402 & 0.0635 & 0.0661 & 0.0653 & 0.0459 & 0.0476 & 0.0563 & 0.0508 & 0.0494 \\
\hline Size & $-0.7525 * * *$ & $-0.7362 * * *$ & $-0.7225^{* * *}$ & $-0.6823 * * *$ & $-1.0778 * * *$ & $-1.0514 * * *$ & $-1.0579 * * *$ & $-1.0050 * * *$ & $-0.7476 * * *$ & $-0.7132 * * *$ & $-0.7196 * * *$ & $-0.7046 * * *$ \\
\hline Density & $-0.4512 * * *$ & $-0.4768 * * *$ & $-0.4925 * * *$ & $-0.5188 * * *$ & $-0.7606 * * *$ & $-0.8046 * * *$ & $-0.8000 * * *$ & $-0.8439 * * *$ & $-0.4508 * * *$ & $-0.4870 * * *$ & $-0.4897 * * *$ & $-0.4950 * * *$ \\
\hline Earthquakes: yes\# & 0.2085 & 0.2252 & 0.2212 & 0.2472 & 0.2343 & 0.2729 & 0.2586 & 0.2835 & 0.2125 & 0.2312 & 0.2285 & 0.2485 \\
\hline Observations & 510 & 510 & 510 & 510 & 510 & 510 & 510 & 510 & 510 & 510 & 510 & 510 \\
\hline R-squared & 0.2433 & 0.2386 & 0.2431 & 0.2422 & 0.3188 & 0.3147 & 0.3154 & 0.3122 & 0.2441 & 0.2389 & 0.2447 & 0.2436 \\
\hline
\end{tabular}




\section{Appendix 3: Regional political power of the governing party based on the percentage}

seats by political party and by change/non-change in government

GovParty: PASOK

GovParty: ND

ChGovParty: Change

ChGovParty: No change

Days

\%GovParty - Seats x ND

\%GovParty - Seats x PASOK

- $\%$ GovParty $=0 \times$ ND

- $0<\%$ GovParty $<50$ x ND

- \%GovParty $=50 \times \mathrm{ND}$

- $50<\%$ GovParty < 100 x ND

- $\%$ GovParty $=100 \times$ ND

- $\%$ GovParty $=0 \times$ PASOK

- $0<\%$ GovParty $<50$ x PASOK

- $\% G o v P a r t y=50 \times$ PASOK

- $50<\%$ GovParty < 100 x PASOK

- \%GovParty $=100 \times$ PASOK

Dif\%GovParty - Seats x ND

Dif\%GovParty - Seats x PASOK

- Dif\%GovParty $=-100 \times$ ND

- $-100<$ Dif\%GovParty < 0 x ND

- Dif\%GovParty $=0 \times$ ND

- $0<$ Dif\%GovParty < 100 x ND

- Dif\%GovParty $=100 \times$ ND

- Dif\%GovParty $=-100 \times$ PASOK

- $-100<$ Dif\%GovParty $<0$ x PASOK

- Dif\%GovParty $=0 \times$ PASOK

- $0<$ Dif\%GovParty < 100 x PASOK

- Dif\%GovParty $=100 \times$ PASOK

\%GovParty - Seats x NO CHA

\%GovParty - Seats x CHANGE

- \%GovParty $=0$ x NO CHA

- $0<\%$ GovParty < 50 x NO CHA

- \%GovParty = 50 x NO CHA

- $50<\%$ GovParty < 100 x NO CHA

- \%GovParty $=100 \times$ NO CHA

- \%GovParty $=0$ x CHANGE

- $0<\%$ GovParty < 50 x CHANGE

- \%GovParty $=50 \times$ CHANGE

- $50<\%$ GovParty < 100 x CHANGE

- \%GovParty $=100 \times$ CHANGE

Dif\%GovParty - Seats x NO CHA

Dif\%GovParty - Seats x CHANGE

- Dif\%GovParty $=-100 \times$ NO CHA

- $-100<$ Dif\%GovParty < 0 x NO CHA

- Dif\%GovParty $=0 \times$ NO CHA

- $0<$ Dif\%GovParty < 100 x NO CHA

- Dif\%GovParty $=100 \times$ NO CHA

- Dif\%GovParty $=-100 \times$ CHANGE

- $-100<$ Dif\%GovParty < 0 x CHANGE

- Dif\%GovParty $=0 \times$ CHANGE

- $0<$ Dif\%GovParty < 100 x CHANGE

- Dif\%GovParty $=100 \times$ CHANGE

GDP per capita

Size

Density

Earthquakes: no

Earthquakes: yes

Time-dummies

Constant

Observations

R-squared

$(1)$
base
$2.4513^{* * *}$
base
$1.8595^{* * *}$
$0.0034^{* * *}$
$0.0029 * *$
$0.0042^{* * *}$

$\begin{array}{cc}(2) & (3) \\ \text { base } & \text { base } \\ 2.5753^{* * *} & 2.4478^{* * *} \\ \text { base } & \text { base } \\ 2.0543 * * * & 1.9237 * * * \\ 0.0038^{* * *} & 0.0035^{* * *} \\ & \end{array}$

(4)

base

$2.5645^{* * *}$

base

$2.0224^{* * * *}$

$0.0037 * * *$

$0.3673 * *$

$-0.0042$

base

0.0060

$0.3813^{* * *}$

$0.5667 * *$

$-0.1917 * *$

base

$-0.0718$

$0.4147^{* * *}$

$0.0021^{* * *}$

$0.0020^{* * *}$

$$
\begin{gathered}
0.3051 \\
-0.0859 \\
\text { base } \\
-0.0958 \\
0.3011^{* * *} \\
0.5339^{* *} \\
-0.2605^{* * *} \\
\text { base } \\
-0.1262^{* *} \\
0.3831^{* * *}
\end{gathered}
$$

$0.0036^{* * *}$

$0.0033^{* *}$
$0.3879 * *$
$-0.1503 *$
base
$-0.0469$
$0.3702 * * *$
$0.4461 * *$
$-0.0493$
base
$-0.0324$

$0.3854^{* * *}$

$0.0018^{* * *}$

$0.0023 * * *$

$0.3792 *$

$-0.2915^{* * *}$

base

$-0.1365 * *$

$0.3038 * * *$

$0.5216 *$

$-0.0576$

base

$-0.0835$

$0.3527 * * *$

0.0176

0.0454

0.0332

0.0495

0.0208

0.0454

0.0326

$-0.0612$

$-0.4516^{* * *}$

base

0.2353

yes

$5.8262 * * *$

510

0.2557
$-0.3888 * *$

base

0.2996

yes

$5.2324 * * *$

510

0.3187
$-0.5820 * * *$
$-0.4684 * * *$

base

0.2304

yes

$5.7824 * * *$

510

0.2592
$-0.4026^{* * *}$

base

0.2941

yes

$5.4058^{* * *}$

510

0.3215
$-0.5949 * * *$

$-0.4436^{* * *}$

base

0.2300

yes

510

0.2551
$5.7860^{* * *}$
$-0.1241$

$-0.3667 * *$

base

0.2824

yes

5.1735 ***

510

0.3142
0.0493

$-0.5812 * * *$

$-0.4690 * * *$

base

0.2293

yes

$5.6869 * *$

510

0.2595
$-0.0873$

$-0.4010^{* * *}$

base

0.2948

yes

$5.2274 * * *$

510

$* * * \mathrm{p}<0.01,{ }^{* *} \mathrm{p}<0.05, * \mathrm{p}<0.1$ 


\section{Endnotes}

${ }^{1}$ More specifically, the 10 political periods are determined by the following 11 national elections: 17-Nov1974; 20-Nov-1977; 18-Oct-1981; 02-Jun-1985; 08-Apr-1990; 10-Oct-1993; 22-Sept-1996; 09-Apr-2000; 07-Mar-2004; 16-Sept-2007; and 04-Oct-2009.

${ }^{2}$ We minimise the problem of having to deal with expenditures unlikely to be affected by political decision-making by running our proposed empirical specification excluding all expenditures more closely related to social well-being (education and research, housing and environment, health and public welfare, and water supply and sewage facilities).

${ }^{3}$ We thank one of the reviewers for this comment.

${ }^{4}$ It should be noted here that the value of the relative political power variable for a particular region can be negative in those cases where the percentage share of votes or seats in favour of the governing party is lower than the percentage share of votes or seats in favour of the main opposition party (RODRÍGUEZPOSE et al., 2012).

${ }^{5}$ The scheme we use for the allocation of the regions to different categories is a combination of an 'exogenous' scheme, defined by criteria external to the distribution of data (e.g. regions with high political power are dominated by the two main political parties in Greece), an 'arbitrary' scheme, in which class boundaries are set by arbitrary criteria, such as equal intervals, and an 'ideographic' scheme, where class boundaries are defined by the shape of the distribution (RODRÍGUEZ-POSE and TSELIOS, 2011). Our regression results are robust to alternative classifications. The regression results using alternative class boundaries and a different distribution of political variables can be provided by the authors upon request.

${ }^{6}$ We control for earthquakes, as earthquakes - Greece being a seismic country - are relatively frequent. They represent important natural disasters which may lead to sudden and profound shifts in the allocation of public investment. According to the Emergency Events Database (see www.emdat.be), the economic costs of an earthquake (i.e. related economic damage) as well as its human cost (i.e. people suffering from physical injuries, trauma or an illness requiring medical treatment as a direct results of an earthquake, people needing immediate assistance for shelter, and people requiring immediate assistance during a period of emergency of an earthquake) is particularly high and implies radical short-term reallocation of public budgets in order to cope with relief and reconstruction operations.

${ }^{7}$ The analysis does not contain GDP and population as control variables, as they are highly correlated with population density (0.9562 and 0.9818 , respectively). GDP and population are also highly correlated (0.9725).

${ }^{8}$ The correlation matrix for all variables can be provided upon request.

${ }^{9}$ We do not combine all regional political power variables into a single index using, for example, principal component or factor analysis, because by merging these proxies into one index we assume that the proxies for political power variables have a systematic interrelationship with one another and are thus part of the same concept. We do not believe that this is the case. The different political power variables used in the analysis explore different political aspects involving the orientation of political parties, their power in 
different constituencies and how time in office may affect expenditure decisions regardless of political orientation. We also explore differences between low, medium and high political power regions through nonlinear effects. We strongly believe that all proxies depicting regional political power should be considered independently from each other. For example, the programme of the Liberal Party in Greece has been usually more 'market-oriented' than that of the Socialist Party, but this says nothing about their respective inclinations to resort to 'pork-barrel' (TSELIOS et al., 2012). Similarly, length in power may affect the temptation to politically influence investments, regardless of the political orientation of the party in office.

${ }^{10}$ The results can be provided upon request.

${ }^{11}$ Apart from Table 4, when the dependent variable excludes expenditures in social well-being. 